\title{
Mollusca, Gastropoda, Succineidae, Omalonyx unguis (d'Orbigny, 1835): Distribution extension and new records for Brazil
}

\author{
Daniel Coscarelli ${ }^{1,2}$ and Teofânia H. D. A. Vidigal ${ }^{2 *}$ \\ 1 Universidade Federal de Minas Gerais, Instituto de Ciências Biológicas, Departamento de Parasitologia. Avenida Antônio Carlos 6627. CEP 31270- \\ 901. Belo Horizonte, MG, Brasil. \\ 2 Universidade Federal de Minas Gerais, Instituto de Ciências Biológicas, Departamento de Zoologia, Laboratório de Malacologia e Sistemática \\ Molecular. Avenida Antônio Carlos 6627. CEP 31270-901. Belo Horizonte, MG, Brasil. \\ * Corresponding author. E-mail: teofania.vidigal@gmail.com
}

\begin{abstract}
Omalonyx unguis was previously known to occur in Argentina, Paraguay and Uruguay. We report the first conclusive record of occurrence of this species in Brazil, based on specimens collected in three localities in the Paraguay River sub-basin (Mato Grosso do Sul state - Campo Grande and Miranda; Mato Grosso state - Poconé), and in the Brazilian margin of the Paraná River (Foz do Iguaçu, Paraná State). The species was identified by comparative morphology of the reproductive system, and a map that synthesizes the literature and reports new records is presented.
\end{abstract}

Omalonyx unguis (d'Orbigny, 1835) is the type species of the genus Omalonyx d'Orbigny, 1837, which comprises neotropical succineid slugs. Although this species has been reported from Brazil on different occasions (Moricand 1836; Hidalgo 1870; 1872; Lange de Morretes 1949; Salgado and Coelho 2003; Simone 2006), information from a recent study (Arruda and Thomé 2008) suggests that those reports may be incorrect.

Tillier (1981) conducted an extensive taxonomic study of the genus using samples from most of the South American countries and the Lesser Antilles. In Brazil, he studied animals from the southern, southeastern, northeastern and northern regions, but did not include specimens from the central western region. Tillier (1981) established $O$. unguis as the senior synonym of most of the southern species of Omalonyx (O. convexus Martens, 1868; O. patera Doring, 1873; O. gallardoi Hylton-Scott and Lapuente, 1968, O. weyrauchi Hylton-Scott, 1970), which resulted in a distribution of $O$. unguis that included Argentina, Paraguay and the southern region of Brazil.

Arruda and Thomé (2008) revalidated the species $O$. convexus and explained that all of the specimens identified as O. unguis by Tillier (1981) were, in fact, O. convexus, with the exception of the paratype from Paraguay (shell only). The map provided by Arruda and Thomé (2008) shows overlapping distributions of the two species in the Argentinean region of the Parana River Basin and adjacent localities in Uruguay. That map also shows that $O$. convexus extends to Rio Grande do Sul state in southern Brazil; while 0 . unguis extends to the Paraguay River sub-basin in Paraguay. This distributional pattern excluded Brazil from the range of 0 . unguis. Hylton-Scott and Lapuente (1968) also reported O. unguis in eight localities, most in Argentina and one in Paraguay. The previously known occurrences of $O$. unguis are summarized in Table 1.

Although there are no consistent records of $O$. unguis occurrence in Brazil, there is no reason to doubt its occurrence in the upper Paraguay River sub-basin of central western Brazil. In fact, this is the only area in Brazil that was not sampled by Tillier (1981). Furthermore, Travassos (1928) used specimens of Omalonyx from Mato Grosso state as experimental hosts for a bird trematode, strongly suggesting that Omalonyx occurs in that area.

The present investigation uses comparative morphology to establish the first record of 0 . unguis in western Brazil. The occurrence of the genus in this region is thus confirmed, and the known geographical distribution of the species is expanded.

The material studied consists of slugs collected (permits granted by IBAMA [SISBIO] \#12113-3) from four localities in western Brazil: Foz do Iguaçu, Paraná state; Campo Grande and Miranda, Mato Grosso do Sul state; and Poconé, Mato Grosso state. All samples were collected from aquatic vegetation on the margins of freshwater systems. One specimen from Miranda is shown in Figure 1. The animals were taken to the laboratory, where they were kept alive until sexual maturity was ascertained by the extrusion of eggs. Mature animals were relaxed overnight in water at $4^{\circ} \mathrm{C}$ and then killed by immersion in hot water $\left(80^{\circ} \mathrm{C}\right)$ for 45 seconds. Shells were removed and stored in dry receptacles, and samples of foot tissue were frozen in an ultra-low temperature freezer $\left(-80^{\circ} \mathrm{C}\right)$ for further molecular studies. Bodies were then preserved in RallietHenry solution (5\% formaldehyde, $2 \%$ acetic acid, $0.6 \%$ sodium chloride). All specimens were deposited in the malacological collection of the Laboratório de Malacologia e Sistemática Molecular (LMSM) in the zoology department of the Universidade Federal de Minas Gerais, Brazil.

Reproductive systems were dissected from the preserved bodies and compared with descriptions of anatomical details that are widely used to identify $O$. unguis (Hylton-Scott and Lapuente 1968; Arruda et al. 2006; Arruda and Thomé 2008) and other species of the genus (Hylton-Scott and Lapuente 1968; Hylton-Scott 1971; Tillier 1980; 1981).

We examined the following Brazilian material: Paraná 
state - Foz do Iguaçu, Refúgio Ecológico Bella Vista, by the margins of the Itaipu Dam, Paraná River, $25^{\circ} 26^{\prime} 49^{\prime \prime} \mathrm{S}$, 54²32'58" W (LMSM 3260, 3269; Coscarelli, D. coll.); Mato Grosso do Sul state - Campo Grande, on the campus of the Universidade Federal do Mato Grosso do Sul, 20³0'19” S, 543'ㄷㄱ" W (LMSM 2747; Coscarelli, D. coll.) and Miranda, Fazenda São Francisco, 20 05'56” S, 5642'34” W (LMSM 2705-08, 2739-42, 2769, 2780-81, 2788, 2795-99, 289899, 2900-08, 2911-13, 2917; Coscarelli, D. and Martins, F. I. coll.); Mato Grosso state - Poconé, Transpantaneira Road, 16²2’30” S, 5640’12" W (LMSM 2673; Coscarelli, D. coll.). The new records of $O$. unguis in Brazil are summarized in Table 2.

The taxonomic characters that we examined matched the diagnosis proposed by Arruda and Thomé (2008), confirming the species identification of the Brazilian specimens as 0 . unguis. That identification was also consistent with the taxonomic information provided by Hylton-Scott and Lapuente (1968) concerning the Argentinean populations of 0 . unguis. The reproductive system, which provides the anatomical features that allow specific identification, is shown in Figure 2. The presence of a serpent-like fold in the surface of the epiphallus (Figure 2D), is the most robust and evident character that is used for the diagnosis of this species.

The presence of $O$. unguis in the material that we examined confirms that the geographical distribution of this species encompasses two hydrological systems in Brazil. The first is the Paraguay River sub-basin, which drains the Pantanal region of western Brazil. The second is the Paraná River where it forms the border between Brazil and Paraguay. These new records extend the range of $O$. unguis northward, and the map in Figure 3 shows the new profile of its distribution.

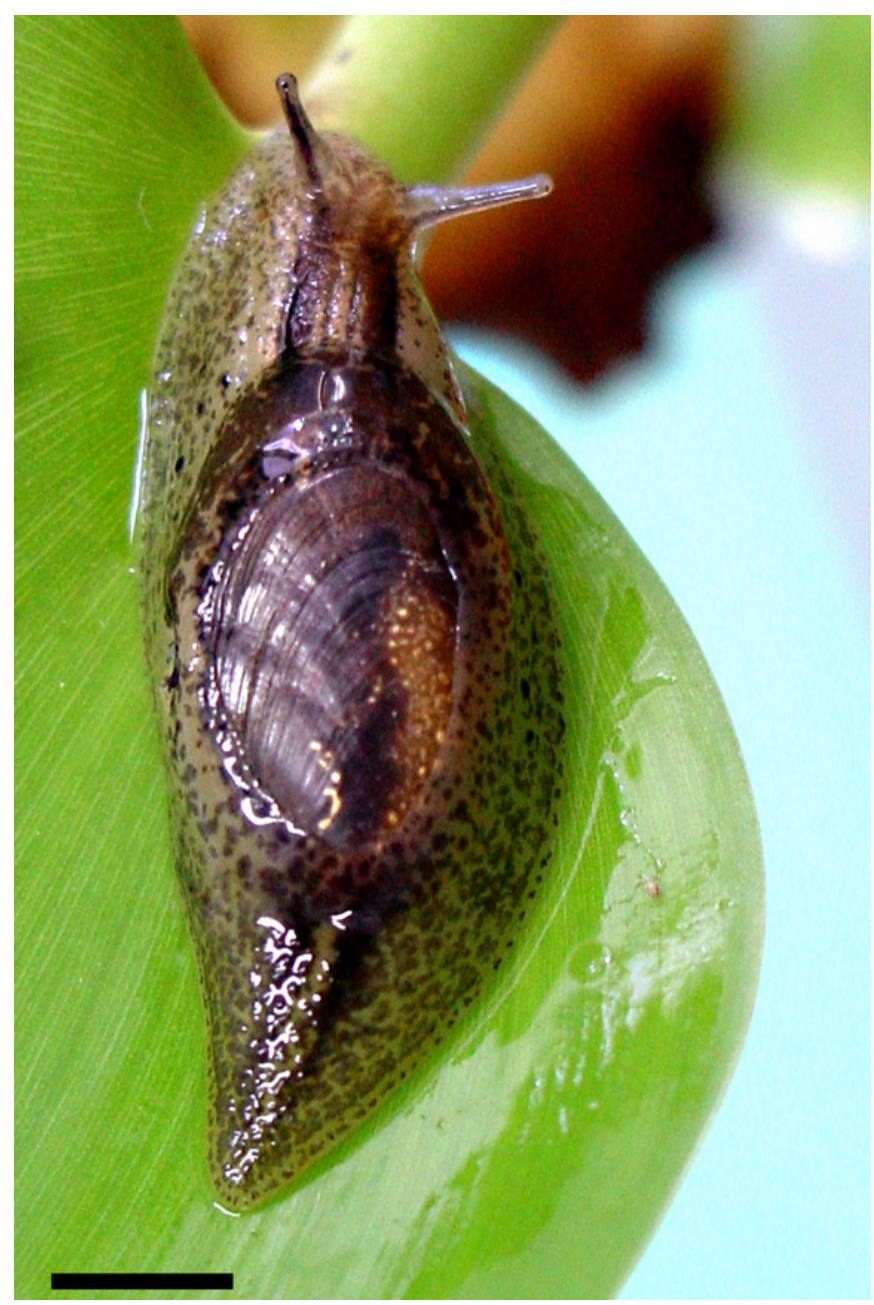

FIGURE 1. Live specimen of Omalonyx unguis on aquatic vegetation from Fazenda São Francisco, in Miranda, Mato Grosso do Sul State, Brazil. Scale bar $=5 \mathrm{~mm}$. Photo: D. Coscarelli.

TABLE 1. Previously known occurrences of Omalonyx unguis, based on reports in the literature.

\begin{tabular}{lll}
\hline COUNTRY & \multicolumn{1}{c}{ LOCALITY } & \multicolumn{1}{c}{ REFERENCE } \\
\hline Paraguay & Puerto Guarani & Hylton-Scott and Lapuente 1968 \\
Paraguay & Asunción & Arruda and Thomé 2008 \\
Argentina & Partido de Tigre & Arruda and Thomé 2008 \\
Argentina & Rosario & Hylton-Scott and Lapuente 1968 \\
Argentina & Rio Santiago, La Plata & Hylton-Scott and Lapuente 1968; Arruda and Thomé 2008 \\
Argentina & Barca Grande, Delta Del Paraná & Hylton-Scott and Lapuente 1968 \\
Argentina & Guaycolec & Hylton-Scott and Lapuente 1968 \\
Argentina & Manantiales & Hylton-Scott and Lapuente 1968 \\
Argentina & Rio de Oro & Hylton-Scott and Lapuente 1968 \\
Argentina & Formosa & Hylton-Scott and Lapuente 1968; Arruda and Thomé 2008 \\
Argentina & Resistência & Arruda and Thomé 2008 \\
Argentina & Villafañe & Arruda and Thomé 2008 \\
Uruguay & Colonia & Arruda and Thomé 2008 \\
\hline
\end{tabular}

TABLE 2. New records of Omalonyx unguis occurrence in Brazil based on recent field collections. LMSM= Laboratório de Malacologia e Sistemática Molecular, Zoology Department of the Universidade Federal de Minas Gerais, Brazil.

\begin{tabular}{lllc}
\hline BRAZILIAN STATE & \multicolumn{1}{c}{ LOCALITY } & \multicolumn{1}{c}{ COLLECTION NUMBER } & $\begin{array}{c}\text { NUMBER OF } \\
\text { DISSECTED ANIMALS }\end{array}$ \\
\hline Mato Grosso & Poconé & LMSM 2673 & 5 \\
Mato Grosso do Sul & Miranda & LMSM 2705-08, 2739-42, 2769, 2780-81, 2788, 2795-99, & 36 \\
Mato Grosso do Sul & Campo Grande & LMS9-99, 2900-08, 2911-13, 2917 2747 & 1 \\
Paraná & Foz do Iguaçu & LMSM 3260, 3269 & 2 \\
\hline
\end{tabular}




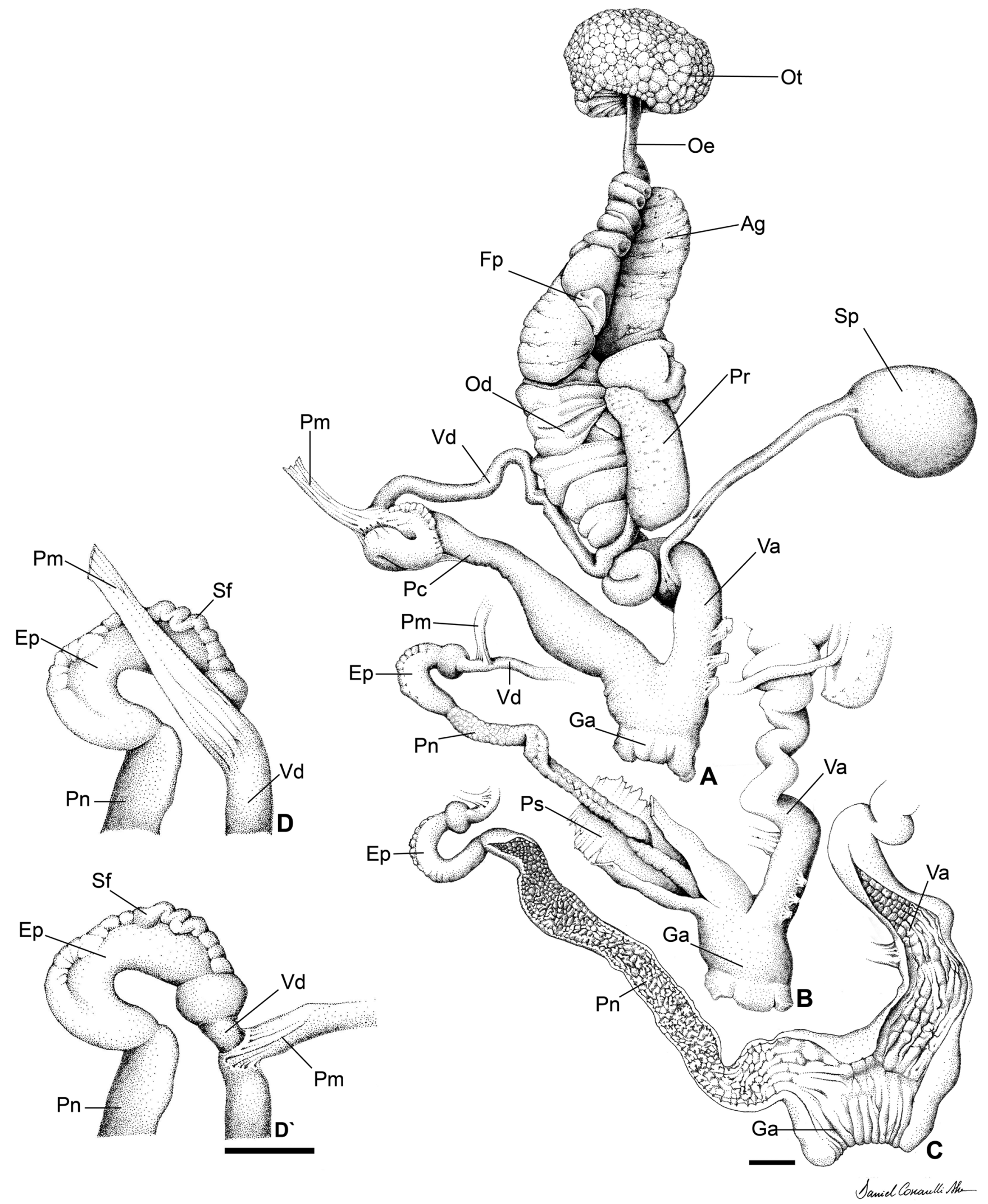

FIGURE 2. Reproductive system of Omalonyx unguis from Fazenda São Francisco, in Miranda, Mato Grosso do Sul state, Brazil (LMSM2707). A. General view of the reproductive system, showing taxonomical characters. B. Penial complex extended and penial sheet broken. C. Open penis, showing the folding pattern on the internal surface. Scale bar $(A-C)=1 \mathrm{~mm}$. D. Emphasis on the epiphallic region, showing the distinct serpent-like fold on the external surface and the insertion point of the penial retractor muscle (D. natural position, D'. stretched muscle) in the vas deferens, which characterizes the species. Scale bar $=1 \mathrm{~mm}$. Ag. Albumen gland. Ep. Epiphallus. Fp. Fecundation pouch. Ga. Genital aperture. Od. Oviduct. Oe. Ovulispermiduct. Ot. Ovotestis. Pc. Penial complex. Pm. Penial retractor muscle. Pn. Penis. Pr. Prostate. Ps. Penis sheet. Sf. "Serpent-like” fold. Sp. Spermatheca. Va. Vagina. Vd. Vas deferens. Illustration: D. Coscarelli. 


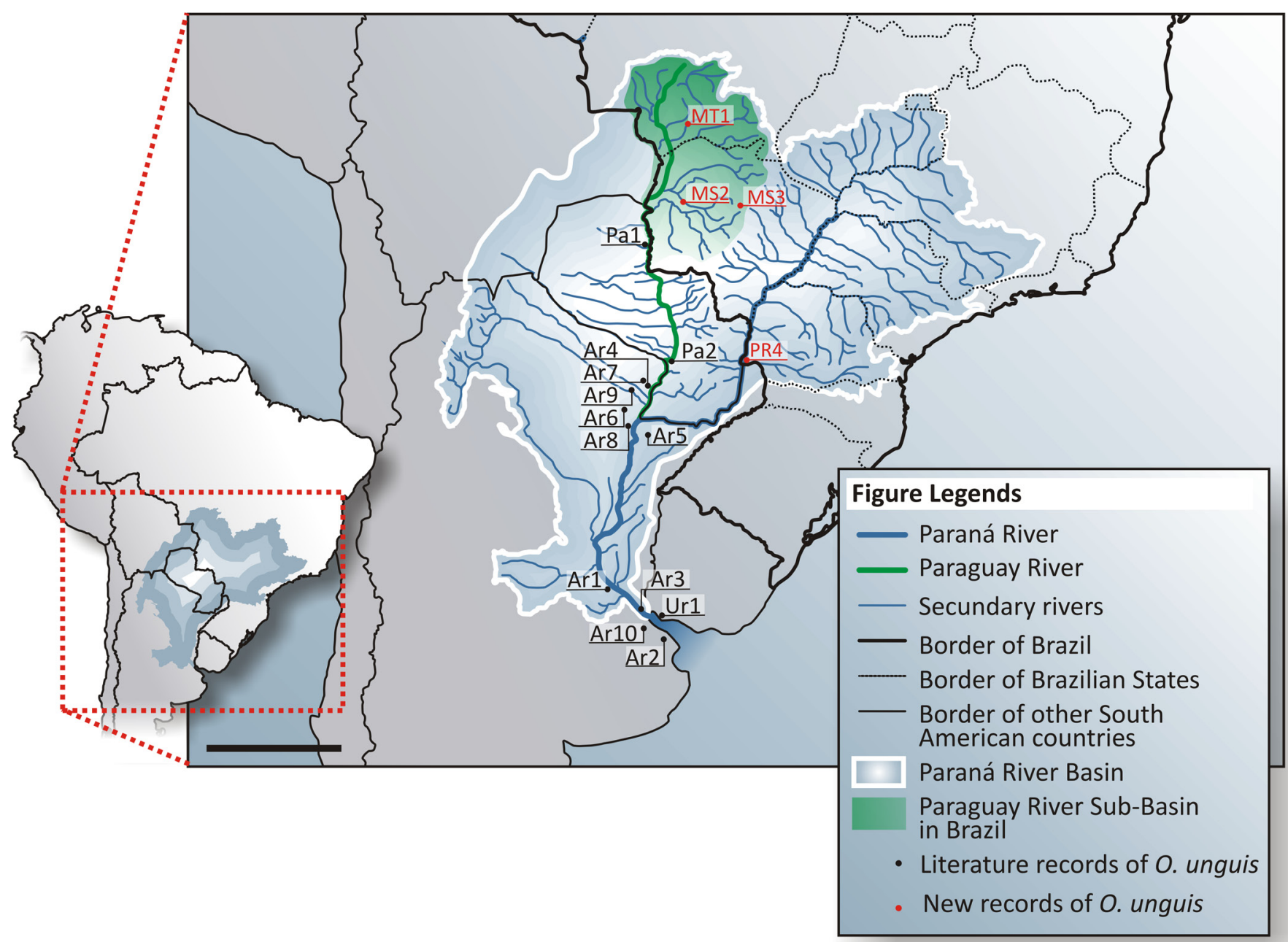

FIGURE 3. Occureces of Omalonyx unguis in South America. The black dots represent previously known as reported by Hylton-Scott and Lapuente (1968) and Arruda and Thomé (2008) and the red dots represent new Brazilian records. Ar = Argentina (Ar1 = Rosario; Ar2 = Rio Santiago, La Plata; Ar3 = Barca Grande, Delta Del Paraná; Ar4 = Guaycolec; Ar5 = Manantiales; Ar6 = Rio de Oro; Ar7 = Formosa; Ar8 = Resistência; Ar9 = Villafañe; Ar10 = Partido de Tigre); MS = Mato Grosso do Sul, Brazil (MS1 = Miranda; MS2 = Campo Grande); MT1 = Poconé, Mato Grosso, Brazil; PA = Paraguay (Pa1 = Puerto Guarani; Pa2 = Asunción); PR1 = Foz do Iguaçu, Paraná, Brazil; Ur1 = Colonia, Uruguay. Scale bar = $1000 \mathrm{~km}$.

ACKNowledgments: We thank Fernando I. Martins, Cláudia M. G. Simeão and Domingo R. Fernandez for extensive assistance with field work. This paper is a part of a project funded by Fundação de Amparo a Pequisa de Minas Gerais (FAPEMIG) (Projeto: CBB-APQ-00918-08). Conselho Nacional de Desenvolvimento Científico e Tecnológico granted a fellowship to D. Coscarelli.

\section{Literature Cited}

Arruda, J.O., S.R. Gomes, R. Ramírez and J.W. Thomé. 2006. Morfoanatomia de duas espécies do gênero Omalonyx (Mollusca, Pulmonata, Succineidae) com novo registro para Minas Gerais, Brasil. Biociências 14(1): 61-70.

Arruda, J.O. and J.W. Thomé. 2008. Revalidation of Omalonyx convexus (Hynemann, 1868) and emendation of the type locality of Omalonyx unguis (Orbigny, 1837). Archive für Molluskenkunde 137(2): 159-166.

Hidalgo, J.G. 1870. Catalogue des coquilles terrestres recueillies par naturalists de la commission scientifique espagnole sur divers points de l'Amérique méridionale. Journal de Conchyliologie 18: 27-70.

Hidalgo, J.G. 1872. Moluscos del viaje al pacífico verificado de 1862 a 1865 por uma comision de naturalistas enviada por el gobierno español. Parte primera, Univalvol terrestres. Madrid: Imprenta de Miguel Ginesta. 155 p.

Hylton-Scott, M.I. 1971. Homalonyx weyrauchi, Nueva especie de Tucuman. Neotropica 17(52): 12-14

Hylton-Scott, M.I. and E. Lapuente. 1968. Valor diagnostico de la Radula para especies del genero Omalonyx Orbigny. Neotropica 14(44): 4956.
Lange de Morretes, F. 1949. Ensaio de Catálogo dos Moluscos do Brasil. Arquivos do Museu Paranaense 7(1): 1-216.

Moricand, S. 1836. Troisième supplément au mémoire sur les coquilles terrestres et fluviates de la province de Bahia. Sociétéde Physique et d'Historie naturelle de Genève, Genébra 7: 415-446.

Salgado, N.C. and A.C.S. Coelho. 2003. Moluscos terrestres do Brasil (Gastrópodes operculados ou não, exclusive Veronicellidae, Milacidae e Limacidae). Revista Biología Tropical 51(3): 149-189.

Simone, L.R.L. 2006. Land and Freshwater mollusks of Brazil. São Paulo: FAPESP. 390 p.

Tillier, S. 1980. Gastéropodes terrestres et fluviatiles de Guyane française. Mémoires de muséum nationale d'Histoire naturelle, Serie A, Zoologie 118: 1-188.

Tillier, S. 1981. South American and Juan Fernandez succineid slugs (Pulmonata). Journal of Molluscan Studies 47: 125-146.

Travassos, L.1928. Fauna helminthológica de Mato Grosso. Trematódeos - Parte I. Memórias do Instituto Oswaldo Cruz 21(2): 309-741.

RECEIVED: December 2010

LAST REVISED: March 2011

ACCEPTED: April 2011

Published OnLINE: July 2011

EDITORIAL RESPONSIBILITY: Inga Ludmila Veitenheimer Mendes 